\title{
Research on Education Reform Method Based on Innovation Ability Training
}

\author{
Yongjia Duan \\ Chengdu Neusoft University, Chengdu, Sichuan,611844
}

Keywords: Innovation, College English Education, Concept, Ability

\begin{abstract}
The innovation and reform of college English education concept is important. The international development of all kinds of talents cannot be separated from the basic training of college English education. The classroom environment, teaching content, teachers' role, education evaluation and the construction of campus English culture innovative construction reform, promote college English education schools to cultivate top-notch innovative talents with international vision and the basis of effective platform. It provides an effective way for cultivating top-notch innovative international talents with critical innovation consciousness.
\end{abstract}

\section{Introduction}

The innovation and reform of education concept in college English plays a very important role. The outline of China's national medium - and long-term education reform and development plan 2010-2020 clearly points out that education exchanges and cooperation in various fields should be carried out at multiple levels to improve the internationalization level of education. This education strategy basically determines the development direction of China's higher education in this decade to go international, and its purpose is to cultivate talents adapted to the increasingly international market demand. College English education has more important tasks in the new era. It needs to strengthen its service and tool functions in the context of internationalization, and it should have the basic conditions of internationalization. Therefore, for college students of all majors, the orientation of teaching objectives and the internationalization of teaching contents are of vital importance. The internationalized development of talents cannot be separated from education's basic cultivation and innovation reform of education, and the innovation reform of education of university English is of great significance in the new era. Education of college English needs to establish a brand new concept of modernization, internationalization and openness with innovative theory. The ultimate goal of this innovation is to cultivate the actual innovation ability of college students.

\section{Innovation Ability and Innovation English Education Concept}

\subsection{The innovation ability}

Innovation refers to the extraordinary ability that people show in the process of transforming nature and society. To be specific, it is an extraordinary creativity. The concept of "innovation ability" is very rich, which requires people to have active inspiration, rich imagination, keen insight, reasonable knowledge structure and unique exploration spirit. Innovation ability includes two aspects: creative thinking ability and creative practice ability. Generally speaking, creative thinking determines people's creative practice, and people's creative practice reflects people's creative thinking, and the two interact with each other. Among them, innovative thinking plays an important role, because the so-called innovative thinking refers to people's thinking ability to use existing knowledge and experience to explore new fields. In other words, people use unique and innovative ideas to pursue the latest knowledge and achieve the purpose of innovation. The essence of innovative thinking is to elevate the consciousness of innovation from perceptual desire to rational exploration stage, and realize the leap from perceptual knowledge to rational thinking. Innovative thinking is an important content in the development of innovative ability, and also one of the basic qualities that should be possessed by innovative talents. Therefore, the development of innovative 
thinking is an important part of innovation education.

\subsection{The innovation education}

Education innovation refers to the innovation activities in education in order to achieve certain education goals in the process of education. Education activities must have specific education goals, and education innovation activities should be carried out around this overall goal. In general, the education goal in China is to constantly improve the quality of all citizens and cultivate talents who can adapt to the social needs of continuous development. In the contemporary society, countries all over the world attach great importance to education innovation. Therefore, in the current education field, no matter the quality of education, innovation education or creation of education, there are very clear targets of education innovation, that is, to cultivate talents with high quality, ability and all-round development to meet the needs of contemporary Chinese social development. The talents cultivated by innovation education should be brave enough to accept new ideas and concepts, and be able to adapt to new changes in social and economic development in a timely manner. The primary task of education workers is to cultivate people with a solid foundation, innovative spirit and pioneering ability. The requirements of education in today's society are essentially the requirements of education workers and education decision makers, which require them to make changes in education content, teaching methods and education policies. Among them, the renewal of teachers' roles and concepts has become a crucial factor, which requires teachers to establish a new education concept and innovative education concept in the teaching process, and constantly stimulate their own innovative consciousness and potential.

\subsection{Innovative education concept in college English}

With the continuous development of society and the advent of global internationalization, people's need and application of English is more and more common. Therefore, the work of college English education must adapt to the requirements of The Times, try to build new teaching modes, explore new teaching approaches, adapt to new situations and solve new problems. In the process of innovation, the innovation of education concept is more important. The innovation of education concept in college English requires educators and decision-makers to get rid of the constraints of traditional education concept, put people first, and explore students' deep cognition, understanding and application of English language. In the process of education, English teachers should try their best to guide students into the most profound English field, digest and absorb the essence of English language, and understand the enlightening role of English culture to us. In the process of education, English teachers should actively cultivate students' ability of divergent thinking, reverse thinking and critical thinking, instead of only teaching students' basic language learning skills. Therefore, the foundation of college English innovation education is to cultivate the innovative thinking quality of students' thinking, good thinking, daring thinking and diligent thinking. For college English teachers who cultivate talents, they should cultivate students' innovative ability in college English classroom teaching, so as to cultivate talents with both innovative ability and English ability.

\section{Innovative English Classroom Environment and Teaching Content}

\subsection{Innovative English classroom environment}

English classroom environment is the place where students participate in English teaching and English teachers implement teaching. In the process of classroom teaching, the teacher's teaching and the student's learning are actually a kind of behavior activity of mutual discussion and learning, and joint solving various problems in learning. In the common teaching process, classroom teaching is an effective process of multilateral activities between teachers and students and between students. English classroom teaching should first create a harmonious, free and relaxed democratic atmosphere for students. In this atmosphere, students should be the subject of teaching and become a highly active, active and original subject to participate in the whole process of classroom teaching. Secondly, in English classroom teaching, teachers should take heuristic teaching ideas as the 
guidance, flexibly use innovative teaching methods, and give play to the role of teachers' innovation guidance. Teachers should creatively use questioning skills to expand students' thinking space and make the teaching process a process of active inquiry. Finally, teachers should actively encourage students to argue with each other, discuss with each other, exchange thinking methods and enlighten each other on the basis of fully studying and understanding students, and carry out the concept of cooperative learning in the English classroom environment. This kind of cooperation must be equal and joyful, so that each student can express his thoughts from his own unique perspective, examine various problems raised in teaching, and make cooperative learning a pleasant and intelligent process.

\subsection{Innovative teaching content}

English classroom teaching content is rich, teaching means is flexible. In terms of teaching content, teachers will choose many other teaching materials for classroom teaching besides textbooks. In addition, flexible and diversified teaching methods are also very important. College English class, the teacher can use such as group discussions, debates, individual report form, can also carry out some distinctive teaching activities, such as the communicative approach to reading teaching, to do some lectures, such as the application of critical thinking in reading, thematic, listening and speaking class reading of writing, novel and poetry interpretation method, etc. In college English teaching, students' cognitive ability, ability to analyze and solve problems should be cultivated, which is a higher requirement for students' innovative thinking on the basis of divergent thinking. In addition, the content of foreign language courses should be internationalized, diversified and marketable. College English courses should be divided into various types, which can be selected by students according to their own needs. For example, we can divide the courses into three types: social application type, interest humanity type and English skill type. The curriculum of social applied English is mainly in line with the society and mainly focuses on social application. Interest humanistic English courses mainly combine knowledge and interest to reflect the humanistic features of The Times. Skill-based English courses are mainly designed for English listening, speaking, reading and writing. The important point of innovative teaching content is to keep up with the latest trend of international development and meet the needs of contemporary society and students themselves. At the same time, innovative teaching should cultivate students' good independent learning awareness and mobilize students' learning initiative.

\section{Fiber Innovative Ability and Innovative Teacher Role and Quality}

The innovative idea and innovative teaching thought of education in college English should focus on the teacher's role and quality innovation. First, college English teachers should be innovators in the content and means of teaching. The whole arrangement of teaching activities should be centered on students' activities and encourage students to think actively and ask questions diligently. Teachers should not only guide students to find English learning problems, but also pay more attention to cultivating students' confidence in English learning. Innovation education requires teachers to trust students, encourage students to think actively and change students' passive acceptance of knowledge. In the classroom environment, students should be provided with sufficient environment and opportunities for language practice, the role of educators and educatees should be changed from teacher-centered to student-centered, and students should be taught the ability to learn independently and acquire knowledge actively. In specific teaching activities, teachers should adopt heuristic teaching as much as possible, and encourage students to dare to raise questions, express their ideas boldly, establish the awareness of innovation, and avoid the mechanization of teaching contents by means of questions and discussion. In addition, teachers should be good at using computer-assisted teaching methods, multimedia and network technologies in teaching, keeping up with the pace of The Times. Second, college English teachers should be the enforcers of education. The so-called motivation education is that educators should start from satisfying students' psychological needs and stimulate students' intrinsic motivation for learning. As the implementers who inspire education, teachers should be good at applying, carrying out 
interesting and novel teaching contents and activities, daring to break through stereotypes and make innovations, striving to create an optimal language environment and psychological environment for students to learn English, and inspiring their desire for further learning. Finally, English teachers should be the communicators of culture. In terms of teaching content, while making reasonable use of teaching materials, teachers should increase the content of English culture, Chinese traditional culture and Chinese minority culture, and enhance students' understanding of English culture and international communication ability of Chinese national culture. Therefore, college English teachers should first have the quality of work enthusiasm and professionalism. At the same time, teachers should actively cultivate their own scientific research quality, information quality, modern teaching technology quality. This requires teachers to continuously update their professional knowledge, train their computer operation skills and network skills, and seize the opportunity to continue education learning.

\section{Innovation Ability and Innovation English Education Evaluation}

To develop students' innovative quality, we must adopt the education evaluation system which is conducive to innovation, and the teaching evaluation system suitable for students will become the motivation for students to learn English. For example, the evaluation of the overall grade of the semester could be focused on formative assessment, and the proportion of the average grade could be increased. Students can be evaluated and supervised in their learning process through self-evaluation, student mutual evaluation and teacher evaluation by means of classroom activity record, online self-study record and extracurricular activity record. Assessment can take many forms, which can make students pay attention to English learning in daily life and make them feel cooperative and competitive in the process of learning. Therefore, teachers' attitudes and methods in the evaluation system are very important. In the process of teaching rating, teachers should take a fair and impartial attitude to evaluate students, give them enough encouragement and support, and give timely and positive feedback to students' learning evaluation results.

\section{Conclusion}

At present, college English education is changing from education to education. The aim of education is to cultivate students' innovative spirit and independent practical ability. In college English teaching, effective and innovative teaching mode and classroom teaching content should be established to cultivate students' innovative thinking ability from multiple perspectives. In the process of cultivating innovative ability, English educators should change their traditional roles and positioning, get rid of the constraints of traditional education concepts, and strive to make innovations in teaching content, teaching methods, teaching means and teaching evaluation system. College English education should be the basis and effective platform for cultivating top-notch innovative talents with international vision, and also an effective way to cultivate top-notch innovative international talents with critical innovation awareness. We should implement English innovation education and strive to cultivate more interdisciplinary and international talents with innovative awareness and ability for the society.

\section{Acknowledgement}

Part of research achievements of the 2017 annual project of Sichuan provincial department of education "Exploration and research on the practice project of English majors in private universities from the perspective of diversified talents".

Item No. 17ZB0015

\section{References}

[1] Liufang Fu, Jianding Yang. Study on the independent learning ability of college English 
teaching model based on network multimedia [J]. English and English teaching, 2007, (10):315-16. [2] Ruiqing Liu, Manchun Dai. Reform of English teaching in Chinese universities: a study of the current situation and development strategies [J]. English teaching and research press, 2008.

[3] Mingyong Mao. Analysis of college English teachers' network ability [J]. English teaching and research, 2017, (2):18-20.

[4] Lei Guo. Complementary research on college English network teaching and traditional teaching [J]. Lanzhou industrial college, 2009(2):22-23.

[5] Department of higher education, ministry of education. Teaching requirements for college English courses (gao hall [2007] no.3) [Z]. 